\title{
Gânduri despre muzică în epoca „reproducerii mecanice“ / Thoughts on Music in the era of "Mechanical Reproduction"
}

\author{
FODOR Attila \\ Departamentul de Arte al Universității Creștine Partium, Oradea / \\ Art Department of Partium Christian University, Oradea \\ fodorattila@partium.ro
}

\begin{abstract}
REZUMAT
Lansat cu aproape un secol în urmă, conceptul de reproducere mecanică a devenit un topos pentru semnificarea influenței tehnicii moderne asupra artei, ridicând inclusiv o serie de întrebări si dileme de ordin estetic. Studiul nostru urmărește $\hat{\imath}$ acest context evidențierea momentelor și tendințelor semnificative survenite în domeniul muzical, analizând manifestarea diferențiată a acestora pe planul creației, interpretării și receptării, prin confruntarea dialogantă a două orizonturi temporale.
\end{abstract}

\section{Cuvinte cheie}

reproducere, tehnică, înregistrare, creație, interpretare, receptare

\section{PRELIMINARII: ADORNO VERSUS BENJAMIN}

Prima jumătate a secolului XX a adus inclusiv în domeniul artei muzicale nu doar schimbări stilisticoestetice mai mult sau mai puțin radicale, dar și intensificarea străduințelor pentru regândirea statutului acesteia într-un context sociopolitic și cultural destul de controversat. În prima linie a acestor preocupări s-a situat Cea de-a doua școală vieneză, susținută pe plan teoretic de așa numitul cerc de filozofie socială de la Frankfurt, în special prin intermediul lui Theodor Wiesengrund Adorno, discipol al lui Alban Berg, care prin vasta și consistenta sa activitate teoretică a devenit apologetul muzicii noi.

Formată în principal din dizidenți neo-marxiști, orientarea caracterizată prin incompatibilitatea cu ideologia sistemelor totalitare (fascismul și comunismul) viza formularea şi promovarea unor alternative de dezvoltare socială. Una dintre directiiile cheie ale acestor preocupări viza tocmai relaţia dintre artă și societate în plină schimbare, ca urmare a dezvoltării tehnice accentuate, cu implicaţii politice-ideologice, dar și de ordin estetic. Stau mărturie în acest sens cercetările avansate asupra efectului social, estetic și politic al radioului și filmului, și în general al artei mediate/multiplicate tehnic.

Din acest corpus consistent și extins vom prezenta succint două studii importante, dar contradictorii: cel al lui Walter Benjamin, publicat în anul 1936, intitulat Opera de artă în epoca reproducerii mecanice

\begin{abstract}
Launched almost a century ago, the concept of mechanical reproduction has become a topos for the significance of the influence of modern technique on art, raising a series of questions and aesthetic dilemmas as well. In this context, our paper aims to highlight the important moments and tendencies that have occurred in the musical field, analyzing their differentiated manifestation in terms of creation, performance, and reception, through the dialogical confrontation of two temporal horizons.
\end{abstract}

\section{Keywords}

reproduction, technique, recording, creation, performance, reception

\section{PRELIMINARIES: ADORNO VERSUS BENJAMIN}

The first half of the 20th century brought not only more or less radical stylistic-aesthetic changes in the field of musical art, but also the intensification of efforts to rethink its status in a rather controversial socio-political and cultural context. In the forefront of these concerns was the Second Viennese School, theoretically supported by the circle of social philosophy known as the Frankfurt School, especially through Theodor Wiesengrund Adorno, a pupil of Alban Berg, who by his vast and consistent theoretical activity became the apologist of the new music.

Consisting mainly of neo-Marxist dissidents, the orientation characterized by an incompatibility with the ideology of totalitarian systems (fascism and communism) aimed to formulate and promote alternatives of social development. One of the key directions of these concerns was the very change taking place in the relationship between art and society, as a result of the accentuated technical development, with political-ideological but also aesthetic implications, attested by the advanced researches on the social, aesthetic and political effect of radio and film, and in general of the mediated/technically multiplied art.

From this consistent and extensive corpus, we shall briefly present two important but contradictory studies: Walter Benjamin's article entitled The Work of Art in the Age of its Technological Reproducibility (Benjamin, 2019), published in 1936, followed two years later by 
(Benjamin, 2019), și cel al lui Adorno, expus cu doi ani mai târziu cu titlul Despre caracterul de fetiș în muzică și regresia auzului (Adorno, 2001). Cu toate că ambele analize evidențiază impactul deosebit al mijloacelor de reproducere în masă asupra modului de existență a artei, ele diferă semnificativ în aprecierea consecințelor. Unul dintre motivele divergenței constă în abordarea unor ramuri incomparabile istoric și estetic: în vreme ce pentru Benjamin noua artă paradigmatică este filmul, definit atât pe planul creaţiei, cât și al transmiterii prin tehnica modernă, Adorno se apleacă asupra muzicii, care în special în privința ramurii culte își menține primordialitatea acustică.

Benjamin analizează particularitatea estetică şi socioculturală a reproducerii tehnice prin confruntarea cu formele tradiționale ale creației şi receptării artei, comparând fotografia cu pictura, și mai ales filmul cu teatrul. Observația sa fundamentală este că o operă de artă concepută într-o formă reproductibilă și/sau reprodusă prin mijloace de multiplicare îşi pierde caracterul de unicat în spaţiu și timp, adică autenticitatea și autoritatea, astfel experiența nemijlocită și irepetabilă magică/sacră/estetică - descrisă prin metafora aurei - nu mai poate fi trăită în plenitudinea ei.

Analizele sale scot la iveală câteva particularități definitorii ale operei reproduse în relație cu receptarea. Astfel este mai obiectivă și detaliată, mai apropiată de experiența cotidiană, de aceea are un potențial manipulativ ridicat. Ieșind din condiționarea spaţio-temporală definitorie a unicității și autenticității (hic et nunc), renunţă la integritatea estetică și la controlul asupra acesteia. Totodată, prin multiplicare crește valoarea ei expozițională în fața celei culturale, adică devine quasi-marfă, drept urmare generează cultul posesiei. Pe planul receptării dizolvă diferența dintre atitudinea critică şi plăcere, promovând convenționalitatea, și sporește superficialitatea receptării în detrimentul celei concentrate, adică pasivitatea şi căutarea plăcerii fără efort. Chiar dacă pentru Benjamin filmul este un model paradigmatic al artei neauratice, acesta prezintă un potențial tehnic-expresiv semnificativ, prin care poate deveni un mijloc de democratizare a maselor.

Dimpotrivă, Adorno a văzut în reproducerea mecanică un pericol asupra autonomiei estetice a creaţiei, a cărei formă supremă de manifestare a formulat-o în elitismul artistic al muzicii noi, exponentul adevărului social prin expresia înstrăinării individului în condițiile capitalismului. În opinia sa muzica mediată tehnic este dirijată de logica mărfii, din care rezultă două momente dialectice semnalate în titlul studiului: fetișizarea operei de artă și regresul auzului. Chiar dacă pe planul creației stabilește o diferențiere categorială (muzica ușoară versus muzica cultă, cea din urmă delimitată în cea progresivă și regresivă), Adorno consideră că din perspectiva consumului întregul fenomen muzical este periclitat, deoarece libertatea alegerii obiectului receptării garantată de judecata estetică se înlocuiește cu aparenta libertate a selectării din supraofertă, astfel funcția estetică este substituită cu rata de popularitate. Reproducerea tehnică şi consumul produsului mediat degradează muzica într-un obiect reificat (fundal sonor), astfel conduce la regresul autonomiei de judecare, implicit la declinul auzului, care
Adorno's paper: On the fetish character in music and the regression of listening (Adorno, 2001).

Though both emphasize the significant impact of mass reproduction on the arts' mode of being, they differ significantly in appreciating its consequences. A matter of divergence between their views is the approach of branches incomparable historically and aesthetically: while for Benjamin the new paradigmatic art is the film, defined both in terms of creation and transmission through modern techniques, Adorno focuses on music, that especially in the so-called classical field maintains its acoustic prevalence.

Benjamin analyzes the aesthetic and socio-cultural particularity of technical reproduction by confronting the traditional forms of creation and reception, comparing photography with painting, and especially film with theatre. His fundamental observation is that a work of art conceived in a reproducible form and/or reproduced by means of multiplication loses its unique character in space and time, that is, its authenticity and authority, and thus the immediate and unrepeatable magical/sacred/aesthetic experience - described by the metaphor of the aura - can no longer be experienced in its fullness.

His analysis reveals some defining features of reproduction regarding its relation to reception. Thus, it is more objective and detailed, closer to daily experience, therefore it has an increased potential for manipulation. Being spared of the time and space conditioning which defines its uniqueness and authenticity (hic et nunc), it gives up the aesthetic integrity and the control over it. Meanwhile, the multiplication increases its exhibition value in comparison to its cultural one, that is, it becomes a quasi-commodity, and as a result it generates the cult of possession. On the level of reception, it dissolves the difference between critical attitude and pleasure, promoting conventionality, and increases the superficiality of reception to the detriment of the concentrated one, that is, the passivity and the seeking of pleasure without effort. Even though for Benjamin the film appears as a paradigmatic model of non-auratic art, it is seen as having a significant technical-expressive potential, and thus as a way of democratizing the masses.

On the contrary, for Adorno, the mechanical reproduction jeopardizes the aesthetic autonomy of the creation, fulfilled in its supreme form by the artistic elitism of the new music, as the exponent of the social truth by expressing the alienation of the individual under the conditions of capitalism. In his opinion, the technically mediated music is guided by the logic of the commodity, manifested in two dialectical moments indicated in the title of his study: the fetishization of the artwork and the regression of hearing. Though he distinguishes several categories of creation (popular music versus art music, the latter delimited as progressive and regressive), Adorno considers that consumption endangers the whole musical phenomenon, since the freedom to choose the artwork guaranteed by the aesthetic judgment is replaced by the apparent freedom of selection from an oversupply, and thus the familiarity becomes a substitute for the aesthetic function. The technical reproduction and consumption of a mediated product degrade the music into a reified object (sound background), thus leading to the regression of the autonomy of judgment, implicitly to 
se transformă în asemenea condiții într-un proces fără obiect și sens (atomizat și disociativ).

Dacă semnificația consumului pare să fie mai evidentă în producerea muzicii ușoare, Adorno observă că mecanismele de funcționare ale acestuia se răsfrâng inclusiv asupra transmiterii și receptării tradiției muzicale, expuse de asemenea tendințelor de fetișizare îndeosebi prin cultul personalităților și șlagărizare. Printre argumentele sale se numără propagarea până la adorație a unor artiști, caracteristici, calități interpretative (dirijori celebri, voci notorii etc.), chiar a unor instrumente (ex. Stradivarius, Amati), precum și prezentarea, respectiv perpetuarea unor părți, secțiuni, fie prin extragerea acestora din contextul original (inclusiv prin transcrierea, adaptarea unor materiale melodicoritmice), fie prin selectarea unor momente pe parcursul audierii unei înregistrări. Acest proces de dezbinare a integrităţii estetice a unei lucrări muzicale conduce la degradarea valorilor în idei. Nu în ultimul rând, reificarea muzicii consumate în acest fel este compensată printr-o afectivitate falsă, plăcerea derivată din accesul sau din posesia cuantificabilă material devenind substitutul efortului ascultării concentrate.

Spre deosebire de film, analizat de Benjamin, existența artei muzicale implică o componentă esențială și în același timp particulară, interpretarea, care în condițiile reproducerii mecanice, adică a înregistrării, suferă o mutație ontologică, fie că vorbim de imortalizarea unui act prin definiție unic și irepetabil, definit spaţio-temporal și sociocultural, fie de promovarea în acest fel a unor perspective închise și ideale.

Din această confruntare sumară a două studii timpurii semnificative sub aspectul investigării relației dintre artă și tehnică rezultă - în opinia noastră - o bogăție de idei și argumente importante, chiar dacă ele au fost concepute într-un orizont temporal relativ îndepărtat și dintr-o perspectivă socio-estetică particulară. Pe cât se pare, timpul scurs de atunci a confirmat în parte tezele formulate, fie că vorbim de optimismul lui Benjamin legat de potențialul filmului ca mediu artistic, fie de constatările lui Adorno în privința efectelor nocive ale comercializării vieții muzicale. Chiar dacă cel din urmă a mai revenit cu trecerea anilor asupra propriilor aprecieri radicale, aversiunea sa față de rolul tehnicii în arta muzicală a rămas în esență nealterată.

\section{MUZICA PRIVITĂ DIN ERA DIGITALĂ}

La jumătate de secol după moartea lui Adorno, orizontul ideatic care a germinat observațiile radicale expuse mai sus pare să fie mai curând utopic, fie că vorbim de intensificarea comercializării vieții și artei, fie de evoluția tehnologică spectaculoasă care, îndeosebi în zilele noastre, împinge experiența umană spre zona virtuală, parcă ireversibil și fără alternativă. Aprecierile legate de efectele acestor schimbări asupra domeniului muzical sunt deosebit de variate, controversate și schimbătoare, chiar dacă o bună parte a realizărilor definite în și prin tehnica modernă au devenit parte a canonului istoric. În cele ce urmează vom evidenția câteva aspecte și tendinţe generale în acest sens prin intermediul parcurgerii sistematice, dar interferente a lanțului trihotomic creațieinterpretare-receptare, inclusiv prin confruntarea implicațiilor diferențiate în creația cultă și cea ușoară. the decline of the hearing, which is transformed in such conditions into a process without object and meaning (atomized and dissociative).

If the significance of consumption seems to be more evident in the production of popular music, Adorno observes that its operating mechanisms are also affected by the transmission and reception of the musical tradition, also exposed to the fetishizing tendencies, especially through the cult of personalities and hits. His arguments include the propagation, to the very brink of worship, of certain artists, characteristics, performing qualities (famous conductors, well-known voices, etc.), even of instruments (e.g. Stradivarius, Amati), as well as the presentation, respectively the perpetuation of parts or sections either by extracting them from the original context (including by transcribing, adapting some melodic-rhythmic materials), or by selecting certain moments during the listening of a recording. The process, which disrupts the aesthetic integrity of a musical work leads to the degradation of values in ideas. Finally, the reification of the music consumed in this way is compensated by a false affectivity, the pleasure derived from the access or possession of an object having a material value becomes a substitute for the concentrated listening effort.

Unlike film, analyzed by Benjamin, the existence of musical art implies an essential and concomitantly particular component, the performance, which under the conditions of mechanical reproduction, that is, of recording, undergoes an ontological mutation, whether we refer to the immortalization of a unique and unrepeatable act, defined both spatially-temporally and socio-culturally, or to the promotion thereby of closed and ideal perspectives.

This brief confrontation of two significant early studies in terms of investigating the relationship between art and technique generates - in our opinion - an abundance of important ideas and arguments, even if they were conceived in a relatively distant temporal frame and from a particular socio-aesthetic perspective. As it seems, history has partially confirmed these theses, whether in terms of Benjamin's optimism about the potential of film as an artistic medium or Adorno's statements regarding the harmful effects of the commercialization of musical life. Even if the latter reformulated some of his radical ideas ulteriorly, his aversion regarding the role of technique in musical art remained essentially unchanged.

\section{MUSIC SEEN FROM THE DIGITAL AGE}

Half a century after Adorno's death, the ideological horizon which germinated the radical observations set out above seems to be rather utopian, whether considering the intense commercialization of life and art, or the spectacular evolution of technology, which especially in our days pushes the human experience towards the virtual area, seemingly irreversibly and without alternatives.

The appraisals regarding the effects of these changes on the musical domain are extremely diverse, controversial and changing, even though a significant part of the achievements defined in and by modern technique have become part of the historical canon. In the following we shall highlight some general aspects and trends in this regard by a systematic and overlapping overview of the creation-performance-reception trichotomy, including the distinctive appreciation of the implications in the field of classical and popular music. 


\section{Creație}

Interferențele creatoare dintre muzică și tehnologie din ultimul secol apar ca ipostaze particulare ale istoriei milenare de dialog fecund dintre artă și științăa cu rădăcinile directe în revoluția industrială din secolul XIX. Valorificarea cotidiană a rezultatelor aplicate ale inovațiilor a avut drept consecință creșterea interesului artiștilor pentru aceste mijloace, ceea ce spre începutul secolului XX a condus inclusiv la formularea unor idealuri alternative de creație. $\mathrm{Nu}$ este aşadar surprinzătoare înmulțirea reflexiilor teoretice din această perioadă, care au previzionat rolul privilegiat al tehnicii în arta viitorului. Alături de scrierile lui Busoni (Schița unei noi estetici muzicale, 1907) sau ale lui Paul Valéry (Cucerirea ubicuității, 1928), se remarcă în acest sens manifestele futuriste, curent care, în ciuda rezultatelor muzicale modeste, a contribuit în mod semnificativ la emanciparea zgomotului ca mijloc de expresie muzicală.

În general putem constata că dezvoltarea tehnică a accentuat interesul compozitorilor pentru parametrul de culoare sonoră, chiar dacă inovațiile în acest sens se înscriu într-o linie firească de evoluție a limbajului muzical, cu fundamentele în romantism. Până în anii 1950 explorările timbrale s-au desfăşurat cu precădere în mediul acustic, fie că vorbim de texturile impresioniste sau pointilismul expresionist, fie de lucrările vizionarului Edgar Varèse, considerat ca fiind părintele muzicii electronice, care, în lipsa unei tehnici adecvate realizării intențiilor sale creatoare - definite ca eliberarea sunetelor (Cox, 2017) - a experimentat cu suprafețe sonore formate din semnale instrumentale ritmizate și perdele de zgomot.

Progresele din prima jumătate a secolului XX în domeniul tehnicii înregistrării şi dezvoltării unor instrumente electroacustice mai performante a făcut posibilă în perioada de după război o schimbare de paradigmă în compoziție. Astfel s-au născut în studiourile de radio din Paris și Köln două metode de abstractizare a sunetului: muzica concretă (Pierre Schaeffer și Pierre Henry) bazată pe manipularea unor evenimente sonore cotidiene înregistrate și muzica electroacustică (König, Stockhausen, Ligeti etc.) realizată exclusiv prin sunete generate şi modulate electronic. Cea din urmă a adus inclusiv o concepție nouă de organizare sonoră, inspirată din tehnica serială. În perioada următoare s-au înființat nenumărate ateliere de experimentare în Europa, Statele Unite și chiar Japonia. În anii 60 apare sintetizatorul modular, iar începând din anii 70 centrele muzicale experimentale bazate pe tehnica de calcul (CCRMA, IRCAM). Epoca digitală a deschis un univers fundamental nou atât în sens calitativ, cât şi în cel cantitativ, fie că vorbim de procesarea mesajelor de eveniment prin protocolul MIDI, fie de procesarea de semnal. Alături de extinderea controlului asupra parametrilor muzicali, facilitat de interfețele vizuale, tehnica digitală a permis un grad ridicat de automatizare, precum și intervenții în timp real, sporind astfel interactivitatea proceselor electroacustice (Loch, 2014).

În aprecierea corelației dintre componistica secolului XX și tehnica modernă remarcăm două aspecte importante. Pe de o parte muzica electroacustică a devenit un mod de expresie în special al avangardei, implicând compozitori de prim rang cunoscuți inclusiv pentru contribuția lor definitorie în mediul acustic. Pe de altă parte există o mare fluctuație în privința ponderii acestor realizări, care

\section{Creation}

The creative interferences between music and technology in the last century appear as particular states of the fruitful millennial dialogue of art and science, with direct roots in the industrial revolution of the $19^{\text {th }}$ century. Since the applied results of the innovations affected the everyday life, the artists' interest in these devices also increased, generating, by the beginning of the $20^{\text {th }}$ century, alternative ideals of creation. The multiplication of theoretical reflections in this period, which anticipated the privileged role of technique in the art of the future, is therefore not surprising. Alongside the writings of Busoni (Sketch of a new aesthetic of music, 1907) or Paul Valéry (The conquest of ubiquity, 1928), we notice in this sense the manifestos of futurism, a current which, despite its modest musical results, has significantly contributed to the emancipation of noise as a means of musical expression.

Generally speaking, the technical development has accentuated the overall interest of composers for the tone colour, even though the innovations in this regard belong to a natural evolution of the musical language, with its foundations in Romanticism. Until the 1950s, timbral explorations took place mainly in the acoustic environment, whether we speak of the textures of impressionism or the pointillism of the expressionism, or of the works of the visionary Edgar Varèse, seen as the father of electronic music, who, in the absence of a proper technique that would fulfilled his creative intentions - defined as the liberation of sounds (Cox, 2017) - was forced to experiment with sound surfaces consisting of repeated instrumental signals and noise backgrounds.

The progress in the field of recording technique in the first half of the $20^{\text {th }}$ century and the development of more efficient electroacoustic instruments enabled a paradigm shift in composition in the post-war period. Thus, two methods of sound abstraction were born in the radio studios of Paris and Cologne: musique concrète (Pierre Schaeffer and Pierre Henry) based on the manipulation of recorded real-world events and electroacoustic music (König, Stockhausen, Ligeti, etc.), consisting exclusively of electronically generated and modulated sounds. The latter also brought a new concept of sound organization, inspired by the serial technique. In the following years several experimental workshops were set up in Europe, the United States and even Japan. During the 60's appeared the modular synthesizer, and starting from the 70 's the experimental music centres based on computer technology (CCRMA, IRCAM). The digital age has opened a fundamentally new universe in both qualitative and quantitative terms, whether in the processing of event messages through the MIDI protocol or in signal processing. Along with the extension of control over the musical parameters, facilitated by the visual interfaces, the digital technique allowed a high degree of automation, as well as interventions in real time, thus increasing the interactivity of the electroacoustic processes (Loch, 2014).

In appreciating the correlation between $20^{\text {th }}$ century composition and modern technique, we notice two important aspects. On the one hand, electroacoustic music has become a way of expression especially for the avant-garde, involving notorious composers also known 
de multe ori par a fi mai curând episodice, experimentale. Un exemplu elocvent ne oferă în acest sens chiar atelierul din Köln: în vreme ce pentru Stockhausen dialogul creator cu mijloacele electroacustice a fost unul durabil și semnificativ, Ligeti a abandonat relativ rapid acest tip de muzică.

Implicații mult mai consistente şi extinse ale tehnicii moderne se regăsesc în sfera aplicată. Amintim în acest sens sound design-ul, adică producerea unor coloane sonore complexe (dialog, zgomote, efecte, muzică) în special pentru genurile audiovizuale (film, teatru, inter- și multimedia), ce implică o mare doză de creativitate, îndeosebi în ilustrarea sonoră a unor situații fără corelat acustic real (de pildă în cazul filmelor științificofantastice).

Dacă pentru domeniul muzicii culte tehnica modernă a fost înainte de toate un mijloc de concretizare a unor intenții creatoare dificil sau imposibil de realizat în sfera acustică, un segment considerabil al genurilor și stilurilor așa numitei muzici ușoare - chiar dacă în mod diferențiat - este dependent de aparaturile electroacustice și tehnica de studio. Un exemplu elocvent în acest sens este populara serie Unplugged lansată de postul Music Television prin anii 90, care, dincolo de reînvierea nostalgică a atmosferei anilor 60-70, a demonstrat în mod indirect semnificația definitorie de stil a acestor mijloace, care se intensifică o dată cu trecerea deceniilor. Mai mult decât atât, fundamentul tehnic a generat un ideal sonor mult diferit de cel al muzicii culte. Aceasta se caracterizează pe de o parte prin tendința de acoperire a spectrului perceptibil cu sunete și armonice, atât prin distribuirea gamelor de frecvență între diferite instrumente și voci (egalizare), cât și în spectrul orizontal (panorama stereo), iar pe de alta prin impulsivitatea dinamică. De aceea, acest tip de creație implică în mod frecvent trei ipostaze confluente: compoziția/interpretarea, aranjament/orchestrație și înregistrare/mixaj/masterizare. Dintre exemplele timpurii notabile amintim în acest sens colaborarea definitorie a trupei Beatles cu George Martin.

Evoluția tehnică continuă a adus așadar, la nivelul creației, beneficii incomparabil mai mari pentru muzica aplicată și cea ușoară. Această constatare este cu atât mai valabilă pentru zilele noastre, cu cât din ce în ce mai multe echipamente utilizate în trecut în lanţul electroacustic sunt accesibile sub formă virtuală (software, plugin) pentru staţiile de lucru audio digitale (DAW), care la rândul lor permit integrarea tuturor momentelor realizării unei producții, de la înregistrare și editare la mixaj și masterizare. Totodată - îndeosebi în stilurile electronice - tehnica se implică în mod definitoriu în configurarea surselor sonore. Reținem în acest sens răspândirea tehnicii de sampling, un instrument fizic sau virtual multifuncțional, care operează cu mostre de sunet interșanjabile și modificabile în diferiți parametri, controlate fie printr-o interfață MIDI, fie printr-un sequencer. Având în vedere evoluția calitativă deosebită a instrumentelor virtuale bazate pe tehnica samplingului, acestea sunt utilizate inclusiv în genuri care implică instrumente acustice (de pildă tobele), astfel cântatul la instrument, ca și înregistrarea propriu-zisă pot fi înlocuite de un act de programare. Așadar era digitală a diminuat în mod simțitor dependența de sesiunile de studio, altminteri destul de for their defining contribution to the acoustic environment. On the other hand, there is a great fluctuation in the significance of these achievements, which often seem to be rather episodic, experimental. An eloquent example is given by the Cologne workshop: whereas for Stockhausen the creative dialogue with electroacoustic tools was a lasting and significant one, Ligeti abandoned this type of music relatively quickly.

More consistent and far-reaching implications of modern technology can be found in the applied field. In this sense we mention the sound design, that is to say, the production of complex soundtracks (dialogue, noises, effects, music), especially for the audiovisual genres (film, theatre, inter- and multimedia), which involves a high dose of creativity, especially in the sound illustration of situations without real acoustic correlation (for example in the case of science-fiction movies).

While for the field of art music, the modern technique was above all a means of achieving creative intentions difficult or impossible to realize in the acoustic sphere, a considerable segment of the genres and styles of popular music is dependent - even though in various manners on electroacoustic equipment and studio technique. An eloquent example in this regard is the popular Unplugged series launched by MTV in the 1990s, which beyond the nostalgic resurgence of the atmosphere of the $60 \mathrm{~s}$ and $70 \mathrm{~s}$, indirectly demonstrated the style-defining significance of these tools, which intensifies with the passage of time. Moreover, the technical basis has generated a sound ideal that is very different from that of art music. This is characterized on the one hand by the tendency to cover the perceptible spectrum with sounds and harmonics, both by distributing the frequency ranges between different instruments and voices (equalization) and in the horizontal spectrum (stereo panorama), and on the other by dynamic impulsivity. Therefore, this type of creation frequently involves three confluent phases: composition/performance, arrangement/orchestration and recording/mixing/mastering. Among the notable early examples, we mention in this regard the defining collaboration of the Beatles with George Martin.

The continuous technical evolution has thus brought, at the level of creation, incomparably greater benefits for applied and popular music. This observation applies even more nowadays, as more and more equipment used in the past in the electroacoustic chain are accessible in virtual form (software, plugin) for digital audio workstations (DAWs), which in turn integrate all moments of a production from recording and editing to mixing and mastering. At the same time, the technique is definitely involved in the configuration of sound sources especially in electronic styles. In this sense we note the spread of the sampling technique, a multifunctional physical or virtual instrument, which operates with interchangeable and modifiable sound samples in different parameters, controlled either through a MIDI interface or a sequencer. Due to the highly qualitative evolution of virtual instruments based on the sampling technique, they are used also in genres that involve acoustic instruments (for example drums), the instrument playing, as well as the recording itself being replaced by a programming act. Therefore, the digital age has diminished the dependence on the - otherwise - quite expensive studio sessions, 
costisitoare, facilitând atât realizarea unor proiecte proprii, cât şi autopromovarea eficientă prin intermediul internetului.

În vreme ce pentru o bună parte a creației culte contemporane partitura (chiar și în cele mai particulare forme de notație) rămâne principalul mijloc de codificare a unei lucrări, piesa de muzică ușoară persistă în primul rând prin finalitatea electroacustică, adică interpretarea este de regulă o condiție sine qua non. De altfel corelația creație-interpretare diferă la nivelul stilurilor, ceea ce în opinia muzicologului Nicholas Cook (2010) are implicaţii estetice. Astfel coincidenţa lor este semnul autenticități, caracteristic în special pentru muzica rock, spre deosebire de stilurile electronice, în care primează interpretarea unui repertoriu compus în prealabil.

\section{Interpretare/transmitere}

Exceptând situațiile utilizării mijloacelor/instrumentelor electroacustice (mai rare în muzica cultă și generalizate în cea ușoară), aproape întreaga sferă a interpretării vizează în contextul studiului nostru mai ales problematica înregistrării. Dacă muzica uşoară este și în această privință mult mai dependentă de tehnică, fie că vorbim de sonoritatea de studio, fie de amplificarea și mixajul live, cea cultă îşi menţine primatul acustic, chiar dacă la modul statistic receptarea acesteia se realizează într-o măsură incomparabil mai mare prin intermediul mijloacelor media. În vreme ce tehnica de înregistrare, stocare şi transmitere a evoluat în mod substanţial în ultimul secol, aprecierea consecințelor estetice pare să primeze și astăzi.

Primul aspect fundamental, sesizat inclusiv de Adorno, vizează însăși intenția de imortalizare a unui act, care în accepțiune tradiţională este unică și irepetabilă. Rădăcinile acestui fenomen se regăsesc în perioada anterioară înregistrării. Astfel pretențiile tehnicoexpresive ridicate ale creației din secolul XIX au condus la profesionalizarea artei interpretative, care a cunoscut o creștere impresionantă în privinţa notorietății și a statutului social al artiștilor. De asemenea, în această perioadă se cristalizează tiparul concertului cunoscut și astăzi, fie că vorbim de apariția recitalului solo, fie de omogenizarea repertoriului interpretat. $\mathrm{Nu}$ în ultimul rând, secolul XIX a lansat o nouă tradiție, cea a perpetuării unui corpus anacronic, ceea ce a condus la o extindere considerabilă, inclusiv în sens cantitativ, a lucrărilor prezentate.

Astfel prestigiul concertului ca act artistic, cât şi ponderea interpreților în economia vieții muzicale a crescut progresiv pe parcursul ultimului secol, fenomen animat într-o măsură considerabilă de arta dirijorală. Din acest punct de vedere înregistrarea n-a făcut altceva decât să întâmpine și să amplifice tendințele amintite. Dacă în zilele noastre a devenit parte integrantă a activității interpretului, reproducerea nu a fost văzută întotdeauna ca o oportunitate. Putem invoca în acest sens două atitudini estetice extreme pro şi contra: pe de o parte cea a dirijorului român Sergiu Celibidache, bine-cunoscut pentru aversiunea sa față de înregistrări, fundamentată din perspectiva filozofică a fenomenologiei, iar pe de alta a pianistului canadian Glenn Gould, pentru care imprimarea şi manipularea acesteia a fost un mijloc primordial în imortalizarea unei viziuni interpretative facilitating both the realization of personal projects and the effective self-promotion through the Internet.

Since for a good part of contemporary art music the score (even in the most particular forms of notation) remains the main means of codifying a work, popular music persists first and foremost through the electroacoustic result, that is, the performance is usually a sine qua non. Moreover, the correlation between creation and performance shows differences between styles, which according to musicologist Nicholas Cook (2010) has aesthetic implications. Thus, their coincidence is seen as the sign of authenticity, characteristic especially for rock music, as opposed to the electronic styles, mainly consisting of the performance of a previously composed repertoire.

\section{Performance/transmission}

Except for the situations of using electroacoustic means/instruments (rarer in art music and generalized in the popular one), almost the entire sphere of performance concerns in the context of our study especially the problem of recording. While the popular music is also in this respect more dependent on technical devices, whether we are talking about the studio sound, or the live amplification and mixing, the art music maintains its acoustic primacy, even though in a statistical sense its reception is incomparably greater through the media. Whereas the technique of recording, storage and transmission has evolved substantially over the last century, the appreciation of aesthetic consequences seems to prevail today.

The first fundamental aspect, noticed by Adorno as well, concerns the intention to immortalize an act, which in a traditional acceptation is unique and unrepeatable. The roots of this phenomenon are found in the period prior to the recording. Thus, the high technical-expressive demands of the $19^{\text {th }}$ century composition led to the professionalization of the art of performance, which experienced an impressive increase in the notoriety and the social status of the artists. Also, during this period, the concert pattern as we know it today began to take shape, whether we speak of the appearance of the solo recital or of the homogenization of the performed repertoire. Finally, the $19^{\text {th }}$ century launched a new tradition, that of perpetuating an anachronistic corpus, which led to a considerable expansion of the presented works also in a quantitative sense.

Thus, the prestige of the concert as an artistic act, as well as the importance of the performers in the economy of musical life has increased progressively over the last century, a phenomenon animated to a considerable extent by the art of conducting. From this point of view, the recording did nothing more than to welcome and amplify the mentioned tendencies. Even though nowadays it has become an integral part of the performer's work, reproduction has not always been seen as an opportunity. In this sense we can invoke two extreme aesthetic attitudes for and against reproduction: on the one hand that of the Romanian conductor Sergiu Celibidache, well known for his aversion to recordings, based on the philosophical perspective of phenomenology, and on the other that of the Canadian pianist Glenn Gould, for whom the recording and its manipulation were an essential means in immortalizing an ideal vision of performance, 
ideale, controlate şi concepute din perspectiva acustică a ascultătorului.

Celălalt aspect vizează schimbarea funcției tehnicilor de transmitere și înregistrare. Dacă într-o primă fază ele au avut menirea primordială de difuzare către un public mai larg - îndeosebi prin transmisiile radio și discurile de vinil - respectiv de documentare, în ultimele decenii acestea au devenit mărturii ale actului interpretativ conștient. Dincolo de beneficiile financiare și promoționale, ele tind să ofere și chiar să impună modele de atitudine artistică, devenind după caz adevărate repere. Muzicologul Nicholas Cook (2010) consideră în acest sens că evidențierea interpreților (chiar și în detrimentul autorilor) în comunicarea caselor de discuri se bazează pe logica primatului creației în aprecierea artei muzicale, adică mitologizarea artistului urmărește înălțarea acestuia la statutul de coautor.

Gradul ridicat de referință al variantelor de interpretare conduce în mod inevitabil la dialog, sau chiar la concurență. Pentru prima situație amintim cele două înregistrări ale lui Glenn Gould cu interpretarea Variațiunilor Goldberg de J. S. Bach, realizate la începutul și finalul carierei de pianist de studio (din 1956, respectiv 1981). În același timp se constată în cazul interpreților consacrați inclusiv în zona înregistrărilor o tendință de imortalizare a unui repertoriu standard important, cum ar fi pentru pianiști Clavecinul bine temperat de J. S. Bach, sau Sonatele pentru pian de Mozart sau Beethoven. Abordarea unor compoziții binecunoscute, fetișizate după cum ar spune Adorno, poate conduce chiar la apariția unor perspective neobișnuite, uneori de-a dreptul șocante, cum ar fi izbitoarea variantă a formației Il Giardino Armonico asupra primelor patru concerte de vioară din seria op. 8 de Vivaldi (Anotimpurile), accesibile în momentul de față în nu mai puțin de 200 de versiuni considerate referențiale.

De altfel, estetica curentului revival (specializat într-o primă fază pentru muzica veche) a adus în acest sens o contribuție semnificativă pe mai multe planuri. Fundamentat în cercetarea științifică a tradițiilor interpretative în special anterioare clasicismului, această orientare a reformulat atât modalitățile de execuție vocalinstrumentală (utilizarea instrumentelor vechi, tehnica inégal, maniere de atac particulare, improvizație și ornamentare etc.), cât și idealul de sonoritate, caracterizat prin transparență, încordare și dinamism, obținut în contextul unor formații eficiente de mai mici dimensiuni. În încercarea de reînviere a unei tradiții orale, sporadic documentate, revival-ul apelează deseori la imaginație (Kelly, 2011), având astfel un caracter experimental pronunțat, manifestat inclusiv în zona înregistrărilor, fie că vorbim de mobilitatea locațiilor, fie de obținerea unor sonorități inedite. $\mathrm{Nu}$ în ultimul rând a impulsionat specializarea interpreților pentru un anumit segment repertorial, precum și identificarea, interpretarea și înregistrarea lucrărilor neglijate sau necunoscute.

$\mathrm{O}$ altă tendință se remarcă în sensul descreșterii cantitative a înregistrărilor cu public, ce ridică deopotrivă probleme tehnice și estetice. Dacă din perspectiva productiilor live audiența apare ca un stimulent artistic, conditiile de studio permit un control de ansamblu tehnic și artistic - mai mare asupra rezultatului final. Transformarea funcției înregistrării dintr-o sursă de controlled and conceived from the acoustic perspective of the listener.

The other aspect concerns the shift in the function of the transmission and recording techniques. While, in a first phase, they had the primary purpose of disseminating music to a wider audience - especially through radio transmissions and vinyl records - respectively of documentation, in the last decades they have become testimonies of a conscious act of performance. Beyond the financial and promotional benefits, the recording tends to offer and even impose models of artistic attitude, eventually becoming real reference points. Musicologist Nicholas Cook (2010) considers in this respect that the highlighting of the performers (even to the detriment of the authors) in the communication of the record companies is based on the logic of the primacy of creation in the appreciation of the musical art, that is to say, the artist's mythologization seeks to elevate them to the status of co-author.

The high reference degree of the performance variants inevitably leads to dialogue, or even to competition. For the first situation we mention the two recordings of Glenn Gould with the performance of Goldberg Variations by J. $\mathrm{S}$. Bach, made at the beginning and at the end of his career as a studio pianist (from 1956 and 1981 respectively). Meanwhile, in the case of the consecrated performers, there is also a tendency to immortalize by recording an important standard repertoire, such as for the pianists Das Wohltemperierte Klavier by J. S. Bach, or the Piano Sonatas by Mozart or Beethoven. The approach of well-known compositions, fetishized as Adorno would say, can even lead to unusual, sometimes shocking perspectives, such as the striking variant of the Il Giardino Armonico on the first four violin concertos of the op. 8 series by Vivaldi (The Four Seasons), currently available in no less than 200 versions considered as referential.

Anyway, the aesthetics of the revival trend (initially specialized in early music) have made a significant contribution in this respect on several levels. Rooted in the scientific research of the past - especially preClassical - traditions of performance, this orientation reformulated both the modalities of vocal-instrumental execution (the use of old instruments, notes inégales, particular manners of attack, improvisation and ornamentation, etc.), and the ideal of sonority, characterized by transparency, tenseness and dynamism, obtained in the context of smaller, efficient ensembles. In the attempt to revitalize an oral, sporadically documented tradition, the revival often appeals to the imagination (Kelly, 2011), thus having a pronounced experimental character, manifested even in the area of recordings, whether we speak of the mobility of the locations or the obtaining of unique sonorities. Finally, it has an effect on the specialization of the performers for a particular repertoire segment, as well as the identification, performance and recording of neglected or unknown works.

Another tendency is noticeable in the quantitative decrease of recordings with public, which raises both technical and aesthetic problems. Whereas from the perspective of live productions, the audience appears as an artistic stimulus, the studio conditions allow a greater 
documentare/mediere informațională într-un produs artistic a redefinit inclusiv relația acesteia față de concertele live, care pe cât se pare se bazează mai curând pe ideea complementarității, decât pe cea a concurenței. Comparând experiența auditivă/idealul sonor al celor două ipostaze observăm mai curând îndepărtarea acestora.

Pe de o parte, reproducerea nu poate modela identic perspectiva spațială reală, nici chiar în cazul sistemelor tip surround. Afirmația este valabilă și pentru fidelitatea calităţii electroacustice, fie și una realizată de cei mai buni specialiști și cu aparatura cea mai performantă, capturată/transmisă la o rezoluție digitală foarte mare (rată de eșantionare și număr de biți). Chiar dacă în zilele noastre se observă o tendință de maximizare a calităţii digitale în limite rezonabile $(96 \mathrm{kHz}, 24$ de biţi), precum şi extinderea numărului de canale audio (în special în domeniul audiovizual), valorificarea acestor oportunități presupune mijloace de redare scumpe și spații de audiție adecvate. Amintim în acest sens eșecul SACD (Super Audio CD) lansat în urmă cu două decenii, care deservește în zilele noastre în special cercul restrâns al audiofililor.

Recunoașterea faptului că înregistrarea nu poate concura cu spectacolul viu, nici ca eveniment sociocultural, nici ca fenomen acustic, a condus la conturarea unei perspective estetice particulare (Ujházy, 2014), ce urmărește o altfel de experiență auditivă, care la rândul ei nu poate fi trăită din diferite motive într-un spațiu real. Amintim în acest sens valorificarea locațiilor de captură alternative, optimizarea/manipularea creatoare a perspectivei sonore sau eliminarea elementelor accidentale nedorite. Din aceste motive se intensifică contribuția artistică a inginerului de sunet și a directorului de înregistrare.

Având în vedere că în domeniul muzicii culte se valorifică și astăzi cu precădere ambientul sonor natural ca sursă de mixaj, variabilele se definesc prin alegerea locaţiei optime în funcție de gen și lucrare (dimensiunea spaţiului, nivelul de reverberaţie, structurarea planurilor sonore etc.), precum şi prin diferitele tehnici de captură (tipul, numărul, poziția şi locația microfoanelor), printre care se numără mai multe variante standardizate de marile studiouri de radio și case de discuri (de exemplu ORTF, Decca Tree etc.)

În vreme ce sălile de concert construite înaintea apariției înregistrării au fost optimizate pentru evenimente cu publicul și după caz pentru anumite genuri (operă, muzică simfonică, muzică de cameră), în ultimele decenii se observă apariția unor spații care, prin integrarea unor elemente mobile, permit modificarea proprietăţilor acustice (de exemplu Palatul Artelor din Budapesta). Totuși, în special datorită segmentului repertorial și idealului sonor particular al curentului revival, asistăm la o diversificare considerabilă a locațiilor, semnificația acestora în economia rezultatului final fiind semnalată inclusiv prin documentarea lor în caietele însoțitoare.

În consens cu tendințele generale din ultimele decenii (să ne gândim doar la metafora Photoshop din domeniul vizual) se remarcă și pe plan muzical o preocupare aparte pentru eliminarea elementelor nedorite din produsele audio lansate pe piaţă, care, dincolo considerentele tehnice de bază (maximizarea semnalului util), vizează în
- technical and artistic - control over the final result. The transformation of the recording's function from a source of documentation/information mediation into an artistic product has redefined its relation to live concerts, which seemingly is based on the idea of complementarity rather than that of competition. Comparing the auditory experience/sound ideal of these two states of being, we observe rather their distancing.

On the one hand, reproduction cannot identically model the real spatial perspective, not even in the case of surround systems. This statement also applies to the fidelity of the electroacoustic quality, even in the case of the best specialists who employ the highest-quality equipment, and capture/transmit sound at a very high digital resolution (in terms of sample rate and bit depth). Even if nowadays there is a tendency to maximize digital quality within reasonable limits $(96 \mathrm{kHz}, 24 \mathrm{bits})$, as well as to expand the number of audio channels (especially in the audiovisual field), the use of these means requires expensive media and adequate audition spaces. In this regard, we mention the failure of SACD (Super-Audio CD) launched two decades ago, which serves nowadays, in particular, the restricted circle of audiophiles.

The recognition of the fact that the recording cannot compete with the live performance, neither as a sociocultural event nor as an acoustic phenomenon, has led to the outline of a particular aesthetic perspective (Ujházy, 2014), which aims at a different auditory experience, which in turn cannot be achieved in a real space, for several reasons. This regards the use of alternative capture locations, the creative optimization/manipulation of the sound perspective or the elimination of unwanted accidental elements. These reasons stress the importance of the sound engineer's and the recording director's artistic contribution.

Considering that in the field of art music, the natural sound environment is used up to these days as a natural source of mixing, the variables are defined by choosing the optimal location according to genres and works (space size, level of reverberation, structuring of sound plans, etc.), as well as by the use of different capture techniques (type, number, position and location of microphones), many of these being standardized by the large radio studios and record companies (for example ORTF, Decca Tree, etc.).

While the concert halls built before the appearance of recordings era were optimized for events with the public and as appropriate for certain genres (opera, symphonic music, chamber music), in the last decades, the newly constructed spaces also include movable elements which allow the modification of the acoustic characteristics (for example the Palace of Arts in Budapest). However, especially due to the particular repertoire and sound ideal of the revival trend, we can notice a considerable diversification of the locations. Their significance regarding the final result is also indicated by the details presented in the booklets of recordings.

Consistent with the general trends of the last decades (let us think of nothing more than the Photoshop metaphor in the visual field), there is also in the world of music a special concern for the elimination of unwanted elements from the audio products released on the market, which, beyond the basic technical considerations (maximizing 
special diminuarea zgomotelor accidentale, inevitabile în cazul concertelor cu publicul, iar din perspectivă muzicală înlăturarea eventualelor erori (sunete greșite etc.) și selectarea chiar și prin montaj a unor momente/variante de interpretare dorite.

În final, fără să înșiruim aici toate etapele de dezvoltare tehnică a mijloacelor de transmisie și stocare audio, reținem doar câteva tendințe fundamentale. Aruncând o privire de ansamblu asupra dezvoltării mass-media, se observă că după o lungă dominație a informațiilor tipărite (cărți, ziare etc.) secolul XX aduce o serie de mijloace noi de comunicare într-o succesiune relativ rapidă. Acest proces de evoluție se poate surprinde atât în plan cantitativ (diversificarea formelor de comunicare și lărgirea accesului la ele), cât și în cel calitativ (optimizarea mediilor pentru anumite tipuri de informații și îmbunătătirea calității generale a transmiterii). Pe plan muzical, exceptând faza incipientă a reproducerilor mecanice, se remarcă două faze fundamentale:

- cea analogică, cu debut în al treilea deceniu al secolului trecut, puțin după lansarea sistematică a emisiunilor de radio, prin implicarea unor mijloace electroacustice (amplificare) între sursă (microfon) și rezultat (transmisie/înregistrare). Până la apariția și răspândirea treptată a tehnologiei digitale începând din anii 70-80, aceasta a traversat numeroase faze de evoluție, obținând rezultate de fidelitate acustică remarcabile. Chiar dacă benzile magnetice au reprezentat o fază tehnică superioară, simbolul acestei ere a rămas discul vinil, care cunoaște în zilele noastre o adevărată renaștere. Defíciența majoră a suportului analogic constă în deteriorarea treptată a acestuia, ca urmare a contactului fizic cu playerul.

- $\quad$ cea digitală, care a pătruns treptat în ultimele decenii ale secolului inclusiv în domeniul muzical. Această tehnologie se bazează pe eșantionarea semnalului audio și stocarea acestuia sub formă de date numerice. Purtătorul simbolic al acestei faze este compact discul, respectiv variațiile acestuia cum ar fi SACD, DVD sau Blu-ray în funcție de destinație (audio sau audiovizual) și cantitatea datelor stocabile.

Răspândirea internetului a schimbat în mod fundamental mass-media, generând pe de o parte noi căi de comunicare bazate pe interactivitate, numite generic noua medie (portaluri, rețele de socializare, site-uri de stocare audio-vizuale), iar pe de alta forțând mijloacele tradiționale la reformularea propriilor misiuni (Potter, 2013). De exemplu radioul, care și-a trăit apogeul în perioada de după război, concurat mai apoi în special de televiziune (să ne gândim doar la contribuția lui Karajan în planul muzicii culte sau a postului MTV în cea ușoară) $\mathrm{s}-\mathrm{a}$ adaptat cu succes noilor condiții prin specializare, similar celorlalte mijloace aparent sortite declinului. Alături de calea digitală terestră, posturile de radio - din ce în ce mai diversificate și particularizate - sunt accesibile și pe internet, cu audiențe relativ mari. De pildă, una dintre cele mai ascultate stații de radio de muzică cultă din Marea Britanie, Classic FM, înregistrează săptămânal o audiență de circa 5 milioane, având o cotă de piață de aproximativ 4 la sută.

Deși tehnica digitală a făcut posibilă prin intermediul internetului răspândirea pe scară largă a înregistrărilor, the useful signal) aims in particular to reduce the accidental noise, inevitable in the case of concerts with public, and, from a musical perspective, to eliminate possible errors (wrong notes, etc.) and to select, even by montage, desired moments/variants of performance.

Finally, without itemizing all the development stages of the audio transmission and storage techniques, we remark only a few fundamental tendencies. Taking an overview of the development of mass-media, we notice that, after a long domination of the printed information (books, newspapers, etc.), the $20^{\text {th }}$ century brings a series of new means of communication in a relatively rapid succession. This evolution process is both quantitative (the diversification of the communication forms and a better access to them) and qualitative (optimizing the media for certain types of information and improving the overall quality of the transmission). On the musical level, except for the incipient phase of mechanical reproductions, there are two fundamental phases:

- The analogue one, which begins in the third decade of the last century, shortly after the systematic launch of radio broadcasts, by involving electroacoustic tools (amplification) between the source (microphone) and the result (transmission/recording). Until the emergence and gradual spread of digital technology in the 70s and 80 s, it had gone through many evolutionary phases, achieving remarkable results in terms of acoustic fidelity. Even though the magnetic tapes represented a higher technical level, the symbol of this era remained the vinyl record, which today is experiencing a true renaissance. The major shortcoming of the analogue carriers is their gradual deterioration due to physical contact with the player.

- The digital one, which gradually spread during the last decades of the $20^{\text {th }}$ century in the field of music as well. This technology is based on the sampling of the audio signal and its storage as numerical data. The symbolic carrier of this phase is the compact disc, respectively its variations such as SACD, DVD or Blu-ray depending on the destination (audio or audiovisual) and the amount of data stored.

The spread of the Internet has fundamentally changed the media, generating on the one hand new ways of communication based on interactivity, generically called the new media (portals, social networks, audio-visual storage sites), and on the other, forcing traditional mediums to reformulate their missions (Potter, 2013). For example, the radio, that lived its heyday in the post-war period, later challenged especially by television (let us think only of the contribution of Karajan in art music or of MTV in popular music) has successfully adapted to the new conditions by specialization, similar to the other means seemingly doomed to decline. Along with the digital terrestrial way, radio stations - increasingly diversified and customized - are also accessible on the Internet, with relatively large audiences. For example, one of the most popular radio stations in the UK, Classic FM, has a weekly audience of around 5 million, with a market share of about 4 percent.

Although digital technology has made possible the widespread of recordings via the Internet, raising major copyright issues, storage considerations and speed limits in data transfer have generated - especially in the first 
ridicând inclusiv probleme mari în privința respectării drepturilor de autor, considerentele de stocare și limitele de viteză în transferul datelor au generat - mai ales într-o primă fază - o stare de compromis în privința calității formatului digital (aşa numitele file-uri lossy), care, deși crește în mod treptat, este de regulă inferioară atât produselor comerciale analogice, cât și celor digitale. Fenomenul este valabil atât pentru majoritatea site-urilor de stocare audiovizuale, cât și pentru aşa numitele servicii streaming (transmiterea datelor sub forma unui flux de informaţii), fie că vorbim despre posturi de radio transmise (și) online, fie de streaming-ul audio, cel puțin în variantele gratuite (Tidal, Spotify, Qobuz, Idagio etc.). Pe cât se pare, declinul compact discului a fost compensat cu succes de aceste servicii. Alături de faptul că oferă un corpus impresionant de înregistrări, imposibil de accesat prin colecționare, ele contribuie inclusiv la legalizarea pieței. Astfel una dintre cele mai mari platforme la ora actuală, Tidal, permite acces la materiale audio inclusiv în calitate CD sau la un standard și mai ridicat, având o bibliotecă care depășește 60 de milioane de albume, dintre care circa un sfert de mare fidelitate.

\section{Receptare/valorificare/analiză}

Receptarea pare să fie domeniul care a suferit schimbările cele mai izbitoare față de perioada de dinaintea apariției mijloacelor electroacustice. Nu întâmplător, observațiile critice ale lui Adorno fuseseră formulate tocmai din această perspectivă. Aprecierea efectelor medierii tehnice continuă să stârnească dispute, chiar mai extinse și diferențiate. Din considerente de spațiu ne vom apleca mai ales asupra aspectelor legate de creația cultă. Este dificil de apreciat ponderea în sine a tehnicii în ansamblul schimbărilor socioculturale și economice majore survenite pe parcursul ultimului secol, care au afectat inclusiv domeniul receptării, ce par a fi mai consistente din perspectiva muzicii uşoare. Lămurirea acestei dileme ar fi importantă inclusiv pentru clarificarea unor stereotipii din zona cultă, cum ar fi presupusa relaţie de cauzalitate dintre răspândirea înregistrărilor și scăderea numerică a publicului.

Există un număr însemnat de cercetări în domeniu (de pildă Classical Music Consumer Segmentation Study, 2002), comandate deseori de organizații muzicale interesate (societăţi muzicale, instituții, corporații media), care prelucrează statistic pe baza unor variabile diferite structura, segmentarea şi obiceiurile de consum ale publicului. În acest context utilizarea mijloacelor de comunicare pare mai degrabă să descrie decât să definească un anumit segment de ascultători, obiceiurile auditoriului fiind influențate mai curând de statutul social-economic, nivelul de cultură, gradul de pregătire muzicală sau posibilităţile de acces. Statistic vorbind radioul are impactul cel mai ridicat în economia receptării muzicale, corespunzând ascultătorului mai puțin devotat pentru viaţa de concert, în vreme ce publicul cel mai activ și interesat este în mod frecvent și colecționar de CD-uri.

Îndeosebi din perioada răspândirii mijloacelor audio portabile, intensificat de cultul gadget-urilor din zilele noastre (smartphone etc.), reproducerea sonoră a populat întreaga sferă acustică cotidiană, devenind chiar un factor al poluării acustice. Una dintre consecințele negative ale reproducerii pare să fie întocmai creșterea volumului phase - a compromise on the quality of the digital format (the so-called lossy files), which, although gradually increasing, is usually inferior to both analogue and digital commercial products. The phenomenon is valid both for the majority of the audio-visual storage sites and for the so-called streaming services (transmission of data in the form of an information flow), whether we are talking about radio stations that broadcast (also) online, or about audio streaming, at least in the free versions (Tidal, Spotify, Qobuz, Idagio, etc.). Apparently, the compact disk's decline has been successfully compensated by these services. Along with the fact that they offer an impressive corpus of records, impossible to access through collecting, they also contribute to the legalization of the market. Thus, one of the largest platforms at the moment, Tidal, gives access to audio materials including CD quality or an even higher standard, with a library exceeding 60 million albums, of which about a quarter of high fidelity.

\section{Reception/exploitation/analysis}

Reception seems to be the area that has undergone the most striking changes compared to the period before the appearance of electroacoustic means. Not by chance, Adorno's critical remarks had been made precisely from this perspective. The assessment of the effects of technical mediation continues to stir up disputes, even more widespread and differentiated. Due to space considerations we will focus particularly on the aspects related to art music. It is difficult to appreciate the importance of the technique itself in the context of all the major socio-cultural and economic changes that occurred during the last century, which also affected the field of reception, and seem to be more substantial in popular music. The clarification of this dilemma is important also in order to shed light on some stereotypes in the art music, such as the supposed causal relationship between the spread of recordings and the decreasing audience numbers.

There is a significant number of researches in the field (e.g. Classical Music Consumer Segmentation Study, 2002), often commissioned by interested music organizations (musical societies, institutions, media corporations), which statistically process, based on different variables, the structure, segmentation, and consumption habits of the public. In this context, the use of the communication means seems to describe rather than to define a certain segment of listeners, the audience's habits being influenced rather by the socialeconomic status, the level of culture, the degree of musical education or the possibilities of access. Statistically speaking the radio has the highest impact in the economy of music reception, corresponding to the listeners less devoted to the concert life, since the most active and interested public also frequently collects CDs.

Especially since the spread of portable audio media, intensified by the cult of gadgets (smartphones, etc.), sound reproduction has occupied the entire daily acoustic sphere, becoming a factor of noise pollution itself. One of the negative consequences of reproduction seems to be precisely the increased volume of the involuntary/passive listening to the detriment of the conscious, concentrated one. Beyond accidental situations, this type of sound background is widely used in the commercial sphere, and 
audiției involuntare/pasive în detrimentul celei conștiente și concentrate. Dincolo de situațiile accidentale, acest tip de background sonor este utilizat pe scară largă în sfera comercială, constituit chiar într-un gen particular numit muzak. În acelaşi timp, diferitele stiluri muzicale sunt asociate frecvent în activitățile de marketing cu un anumit public țintă, ceea ce demonstrează existența unei funcții de segmentare socială. $\mathrm{Cu}$ alte cuvinte, a asculta un tip de muzică înseamnă de multe ori a aparține unui grup pe diferite coordonate valorice și comportamentale.

În acest univers sonor complex şi chiar haotic, caracterizat printr-o imensă varietate de impulsuri și posibilităţi, problema majoră a receptării pare să fie selectarea și asigurarea condițiilor spațio-temporale ale ascultării, necesare pentru valorificarea funcției estetice a lucrării muzicale. De vreme ce sala de concert rămâne sursa primordială a experienței estetice muzicale culte, înregistrările pot îndeplini o serie de funcții complementare.

În ciuda mobilității din zilele noastre, accesul la evenimente muzicale semnificative este în continuare problematic, în special pentru populația din zonele îndepărtate de marile centre culturale. Astfel, transmiterea audio sau audiovizuală rămâne o alternativă importantă, fie că vorbim de posturi de televiziune sau de radio, fie de inițiative particulare, cum ar fi cea a Filarmonicii din Berlin sub fosta îndrumare a maestrului Sir Simon Rattle, numită Digital Concert Hall, care oferă abonamente la concertele formației transmise în direct prin internet la o calitate audiovizuală superioară. Se remarcă de asemenea apariția unor servicii de streaming dedicate muzicii culte cum ar fi Idagio, fonoteci imense, în care se regăsesc înregistrări despre lucrări, variante interpretative greu accesibile chiar și pentru auditoriul privilegiat din centrele de referință.

$\mathrm{Nu}$ în ultimul rând, trebuie să amintim pe scurt câteva dintre beneficiile tehnicii moderne sub aspectul educației și cercetării. Datorită efemerității acustice a fenomenului muzical, înregistrarea are o funcție importantă de documentare, fie că vorbim de imortalizarea unor tradiții orale, cum este folclorul, fie de surprinderea unor momente interpretative de mare valoare istorică, sau de rolul de feedback în educația vocală-instrumentală. Din perspectiva cercetării, documentarea sonoră apare ca un suport analitic și demonstrativ important, valorificat inclusiv pe planul educației.

În ultima perioadă sfera preocupărilor muzicologice și critice s-a extins inclusiv asupra interpretării muzicale înregistrate. Avem în vedere introducerea disciplinei interpretării comparate în programa universitară, inclusiv prin utilizarea unor softuri dedicate de analiză (de exemplu Sonic Visualiser), prin care se pot vizualiza și compara statistic pe diferite coordonate particularităţile unor variante de interpretare (tempo, fluctuații, timbru, dinamică, chiar formă), ceea ce contribuie într-o mare măsură la înțelegerea modalităților diferențiate de transmitere a mesajului și a sentimentelor însoțitoare dintr-o lucrare.

În zilele noastre înregistrările fac parte organică din viaţa muzicală, astfel activitățile critice tradiționale tind să se extindă inclusiv asupra acestui segment. Dincolo de motivațiile promoționale, ele vizează deopotrivă analiza unor particularități muzicale și tehnice, prezentate atât pe paginile unor magazine specializate, cât și în emisiuni radio. has even given birth to a particular genre called muzak. At the same time, the different musical styles are frequently associated in the marketing activities with a certain target audience, which demonstrates the existence of a social segmentation function. In other words, listening to a type of music often means belonging to a group on different values and behavioural coordinates.

In this complex and even chaotic sound universe, characterized by a huge variety of impulses and possibilities, the major problem of reception seems to be the selection and assurance of the spatial-temporal conditions of listening, necessary for capitalizing on the aesthetic function of the musical work. Since the concert hall remains the primary source of aesthetic experience for art music, the recordings can fulfil a number of complementary functions.

Despite today's mobility, access to significant music events is still problematic, especially for the population in areas far from major cultural centres. Thus, audio or audiovisual transmission remains an important alternative, by means of television or radio stations, or by private initiatives, such as that of the Berlin Philharmonic, under the former leading of Sir Simon Rattle, called Digital Concert Hall, which offers subscriptions to the orchestra's concerts transmitted live over the internet with a high audiovisual quality. We also notice the emergence of streaming services dedicated to art music such as Idagio, huge audio libraries that contain recordings about works and performance versions that are hard to find even for the privileged audience living in major cultural centres.

Finally, we must briefly mention some of the benefits of modern technology in terms of education and research. Due to the acoustic ephemerality of the musical phenomenon, recording has an important function of documentation, whether we are talking about immortalizing oral traditions, such as folklore, capturing performances of a great historical value or the role of feedback in vocal-instrumental education. From the perspective of research, the documentation of sound appears as an important analytical and demonstrative support, on the educational level as well.

Recently, the scope of musicological and critical concerns has also expanded towards the recorded musical performance. We consider the introduction of comparative performance as a discipline in the university curriculum, including the use of dedicated analysis software (for example Sonic Visualiser), through which the particularities of performance variants (tempo, fluctuations, tone colour, dynamics, even form) can be viewed and compared statistically, which contributes to a great extent to the understanding of the differentiated ways of transmitting the message and the accompanying emotions from a piece of music.

The recordings are nowadays an organic part of the musical life, so that the traditional critical activities tend to extend upon this segment too. Beyond the promotional motivations, they also aim to analyze musical and technical features, presented both on the pages of specialized magazines and in radio shows. 


\section{ÎN LOC DE CONCLUZII}

Pentru multă vreme accesul omului de rând la cultură şi educaţie de calitate a fost un vis zadarnic, ceea ce s-a schimbat în mod fundamental în ultimul secol. Desigur, arta exista şi înflorea înaintea tehnologiei reproducerii, iar din perspectiva muzicii culte - cu anumite excepții se pare că ar putea exista fără aceasta.

Schimbările socioculturale au produs în fiecare epocă reacții critice, și totuși arta s-a adaptat de fiecare dată noilor condiții. Aceasta presupune însă înțelegerea fenomenelor și valorificarea oportunităţilor. Or cheia este în acest sens educația, care trebuie să fie capabilă nu doar de transmiterea de valori și formarea de competențe muzicale, dar și de pregătirea - chiar și critică - a societății în vederea fructificării rezultatelor spectaculoase ale științelor aplicate.

\section{INSTEAD OF CONCLUSIONS}

For a long time, the access of ordinary people to quality culture and education was a hopeless dream, which changed fundamentally in the last century. Of course, art existed and flourished before the technology of reproduction, and from the perspective of art music with certain exceptions - it seems that it is not a sine qua non.

Sociocultural changes have produced critical reactions in each era, yet art has always adapted to the new conditions. However, this involves understanding the phenomena and exploiting the opportunities. The key is in this sense the education, which must be capable not only of transmitting values and training musical competences, but also of preparing - even critically - the society in order to exploit the spectacular results of the applied sciences.

\section{BIBLIOGRAFIE / REFERENCES}

[1] Adorno, Wiesengrund, and Bernstein, Jay M. (2001). The Culture Industry. Selected essays on mass culture. London and New York: Routledge.

[2] Baker, Tim (2000). Stop re-inventing the wheel: a guide to what we already know about developing audiences for classical music. Association of British Orchestras.

[3] Benjamin, Walter, and Arendt, Hannah (2019). Illuminations. Essays and reflections. New York: Mariner Books.

[4] Borio, Gianmario (2016). Musical Listening in the Age of Technological Reproduction. Farnham: Ashgate Publishing Limited.

[5] Classical Music Consumer Segmentation Study (2002). Southport: Audience Insight LLC.

[6] Cook, Nicholas (2010). Music: a brief insight. New York: Sterling Publishing.

[7] Cook, Nicholas, and Clarke Eric, and Leech-Wilkinson, Daniel, and Rink, John (2009). The Cambridge Companion to Recorded Music. Cambridge: Cambridge University Press.

[8] Cox, Christoph, and Warner, Daniel (2017). Audio culture. Readings in Modern Music (Second Edition). New York: Bloomsbury Academic.

[9] Holmes, Thom (2008). Electronic and experimental music. Technology, music, culture (Third Edition). New York\&London: Routledge.

[10] Katz, Mark (2004). Capturing sound: how technology has changed music. Berkeley and Los Angeles\&London: University of California Press.

[11] Kelly, Thomas Forrest (2011). Early music: a very short introduction. Oxford\&New York: Oxford University Press.

[12] Loch Gergely, and Szigetvári Andrea (2014). Az elektroakusztikus zene története. Budapest: Typotex.

[13]Philip, Robert (2004). Performing Music in the Age of Recording. New Haven and London: Yale University Press.

[14]Potter, W. James (2013). Media literacy (Sixth Edition). Thousand Oaks and London: SAGE Publications.

[15] Taylor, Timothy D. (2001). Strange Sounds. Music, Technology and Culture. New York and Oxon: Routledge

[16] Ujházy László (2014). A hangfelvétel dicsérete (Second Edition). Budapest: Gramofon Könyvek.

[17] https://media.info/radio/stations/classic-fm/listening-figures

[18] (accessed: 08.03.2020) 